\title{
Cell death and degeneration in the symbiotic dinoflagellates of the coral Stylophora pistillata during bleaching
}

\author{
D. J. Franklin ${ }^{1,3, *}$, O. Hoegh-Guldberg ${ }^{2}$, R. J. Jones ${ }^{2}$, J. A. Berges ${ }^{1,4}$ \\ ${ }^{1}$ School of Biology and Biochemistry, The Queen's University of Belfast, 97 Lisburn Road, Belfast BT9 7BL, Northern Ireland, UK \\ ${ }^{2}$ Centre for Marine Studies, University of Queensland, Brisbane, Queensland 4072, Australia

\begin{abstract}
${ }^{3}$ Present address: Centre for Marine Studies, The University of Queensland, Brisbane, Queensland 4072, Australia
\end{abstract} \\ ${ }^{4}$ Present address: Department of Biological Sciences, University of Wisconsin-Milwaukee, 3209 N Maryland Avenue, \\ Milwaukee, Wisconsin 53211, USA
}

\begin{abstract}
Rising sea temperatures are increasing the incidences of mass coral bleaching (the dissociation of the coral-algal symbiosis) and coral mortality. In this study, the effects of bleaching (induced by elevated light and temperature) on the condition of symbiotic dinoflagellates (Symbiodinium sp.) within the tissue of the hard coral Stylophora pistillata (Esper) were assessed using a suite of techniques. Bleaching of $S$. pistillata was accompanied by declines in the maximum potential quantum yield of photosynthesis $\left(F_{\mathrm{v}} / F_{\mathrm{m}}\right.$ measured using pulse amplitude modulated [PAM] fluorometry), an increase in the number of Sytox-green-stained algae (indicating compromised algal membrane integrity and cell death), an increase in $2^{\prime}, 7^{\prime}$-dichlorodihydrofluroscein diacetate $\left(\mathrm{H}_{2} \mathrm{DCFDA}\right)$ stained algae (indicating increased oxidative stress), as well as ultrastructural changes (vacuolisation, losses of chlorophyll, and an increase in accumulation bodies). Algae expelled from S. pistillata exhibited a complete disorganisation of cellular contents; expelled cells contained only amorphous material. In situ samples taken during a natural mass coral bleaching event on the Great Barrier Reef in February 2002 also revealed a high number of Sytox-labelled algae cells in symbio. Dinoflagellate degeneration during bleaching seems to be similar to the changes resulting from senescence-phase cell death in cultured algae. These data support a role for oxidative stress in the mechanism of coral bleaching and highlight the importance of algal degeneration during the bleaching of a reef coral.
\end{abstract}

KEY WORDS: Symbiodinium - Coral bleaching · Temperature/light stress · Global climate change · Ultrastructure $\cdot$ Dinoflagellate $\cdot$ Symbiont

\section{INTRODUCTION}

Bleaching of corals (the dissociation of the coral-algae symbiosis during periods of elevated seawater temperature) is threatening the persistence of reef communities world-wide (Hoegh-Guldberg 1999). The molecular, cellular and physiological mechanisms associated with coral bleaching are not yet fully understood. Most of the attention in recent years, however, has been on processes within the algal symbionts, since the discovery that photosynthesis of the algal symbiont in the host coral (in symbio) is reduced by elevated light, elevated temperature, and a combination of elevated light and temperature (Warner et al. 1996, Jones et al. 1998). These reductions in photosynthetic efficiency are synonymous with a decline in the population of functional reaction centres in a process known as photoinhibition (Long et al. 1994). Photoinhibition precedes the loss of algae from the tissues and tissue discolouration (bleaching). Several mechanisms have been proposed to explain the thermal sensitivity of the algal symbionts including the effects of temperature on the dark re- 
actions of photosynthesis and the carbon acquisition process (i.e. sink limitation, Jones et al. 1998), the donor side of Photosystem II (PSII, Iglesias-Prieto \& Trench 1997), and the D1 protein repair mechanism (Warner et al. 1999).

Many studies have also implicated oxidative stress as the cause of coral bleaching (Lesser \& Shick 1989, Lesser et al. 1990), since corals (and other cnidarians) routinely experience highly elevated $\mathrm{pO}_{2}$ in their tissues (Dykens \& Shick 1982). Reactive oxygen species (ROS), are an inevitable by-product of photosynthesis due to the difference in redox potential between photosynthesis reactants and products (Niyogi 1999). A proportion of the oxygen consumed by mitochondria during respiration undergoes further univalent reduction to form superoxide ion. An elaborate antioxidant capacity exists in all cells to minimise the damage ROS can produce, and in corals, both the host and the algal symbiont produce increased levels of antioxidant defence enzymes such as superoxide dismutase and catalase under elevated light and temperature stress (Dykens \& Schick 1982, Dykens et al. 1992, Lesser 1996). The central role of ROS in triggering cell death throughout diverse cell types (Jabs et al. 1996) suggests that accumulations of ROS should be deleterious for the symbiotic algae of corals.

The links between algal degeneration in symbio, photosynthetic stress, and bleaching have not been specifically addressed. The degeneration of symbiotic algae in symbio is a routine process, as their populations turn over (i.e. as cells divide, grow old and die). Degenerate algae in symbio have been reported for at least 70 yr (Yonge \& Nicholls 1931), and have typically been identified by an increase in the number of vacuoles, disorganisation of thylakoids, enlargement of the accumulation body, and the accumulation of lipids (Yonge \& Nicholls 1931, Freudenthal 1962, Trench 1974, Brown et al. 1995, Le Tissier \& Brown 1996, Salih et al. 1998, Dunn et al. 2002). A greater number of algal symbionts appear to degenerate during periods of environmental stress, e.g. unseasonally warm water temperatures (Yonge \& Nicholls 1931), and there is a growing appreciation of the importance of algal cell death during the bleaching of symbiotic invertebrates. Whilst in these studies the term 'degeneration' has been used, the terms death and disintegration could provide a more accurate description of the process. A recent study notes a number of morphological similarities between degenerating dinoflagellate symbionts and metazoan cells that have died as a result of programmed cell death, raising the possibility that dinoflagellate symbionts undergo a form of active cell death which they themselves mediate (Dunn et al. 2002). Although expulsion of algal symbionts is widely accepted as the mechanism of algal loss from coral tissue during bleaching (Hoegh-Guldberg \& Smith 1989), the question of why expulsion occurs in the first place requires further clarification. Necrosis and apoptosis are twinned concepts in metazoan cell research, necrosis representing a passive form of cell death which is not dependent on new gene expression, whereas apoptosis on the other hand is a process in which the cell is an active participant in its own demise. Necrotic or apoptotic cell death of the algal symbionts may be associated with the coral bleaching response (Dunn et al. 2002). The morphological criteria for identifying necrosis versus apoptosis are well accepted in metazoan cells, but in algal protists the biochemical characterisation of these processes is just beginning (e.g. Berges \& Falkowski 1998).

The photosynthetic health of algal symbionts is better known, and there is now an accumulation of evidence suggesting that photosynthesis of the algal symbionts is impaired during heat stress, that active oxygen species are associated with the stress response, and that damage to the algal symbionts occurs in symbio. Despite this, coupled measurements of coral photosynthetic efficiency and algal morphology during light/temperature stress have been attempted only once. Salih et al. (1998) found that in short (8 h) stress exposures, reductions in photosynthetic capacity were accompanied by algal degeneration. In this study we examine the response of symbiotic algae from the hard coral Stylophora pistillata to increased light, increased temperature, and a combination of increased light and temperature. S. pistillata is a common branching coral that is recognised as a thermotolerant species inhabiting a range of reef environments from reef flat to deeper water. We measured the photosynthetic efficiency of the algae in symbio with chlorophyll fluorescence techniques, we used cell staining techniques to record oxidative stress and cell viability and, finally, morphological characteristics of the algae were examined using transmission electron and light microscopy. We conclude that coral bleaching conditions kill symbiotic dinoflagellates. The morphology of cell degeneration suggests the involvement of the cell death process also seen in dying cultured algae cells, i.e. the process seen during cell senescence.

\section{MATERIALS AND METHODS}

Coral collection, maintenance and experimental treatments. All experiments were conducted with small (3 to $5 \mathrm{~cm}$ long) terminal branches (explants) of the hard coral Stylophora pistillata (Esper) collected from the protected intertidal reef flat in 1 to $2 \mathrm{~m}$ depth at Heron Island Reef $\left(23^{\circ} 26.5^{\prime} \mathrm{S}, 152^{\circ} 0^{\prime} \mathrm{E}\right.$, Great Barrier Reef, Australia). S. pistillata was used because it is a 
common and widely distributed species, the dinoflagellate symbionts are monocladal for depths of 0 to $5 \mathrm{~m}$ (Clade $\mathrm{C}_{i} \mathrm{~W}$. Loh pers. comm.), and the coral tissue is thinly veneered over the skeleton which allows efficient extraction of algal cells and measurement of algal photosynthetic efficiency. Explants were created by clipping off branches from colonies in situ using a hand-held surgical bone-cutter. Explants were then returned to the Heron Island Research Station (HIRS), or the Centre for Marine Studies (The University of Queensland), vertically mounted into plastic holders using modelling clay, and kept in aquaria under baseline (close to ambient) conditions. At HIRS, corals were kept at 25 to $27^{\circ} \mathrm{C}$ in flow-through aquaria under natural sunlight, where maximum photosynthetically active radiation (PAR) was 300 to $400 \mu \mathrm{mol}$ quanta $\mathrm{m}^{-2}$ $\mathrm{s}^{-1}$ measured with a L1-1000 light meter (Li-Cor). At the University of Queensland, corals were kept at $26^{\circ} \mathrm{C}$ in closed aquaria systems under $300 \mu \mathrm{mol}$ quanta $\mathrm{m}^{-2} \mathrm{~s}^{-1}$ of artificial light (see following paragraph). All corals were kept for at least $3 \mathrm{~d}$ prior to use in experiments.

In recognition of the fact that light and temperature act synergistically in the bleaching of corals (Jokiel \& Coles 1977), corals were exposed to combinations of light and temperature that were designated as a high stress (HS), and a low stress (LS) experimental treatment. The combinations of light and temperature stress that we selected were based upon multiple preliminary range-finding tests (pre-experiments), the known thermal (Jones et al. 1998) and light (Jones \& Hoegh-Guldberg 2001) tolerances of Stylophora pistillata, and upon temperatures measured during past bleaching events at Heron Island. To examine the response of corals to a high stress (HS) treatment (i.e. an extremely physiologically challenging combination of temperature and light), corals were exposed for $8 \mathrm{~h}$ to $32^{\circ} \mathrm{C}\left( \pm 1^{\circ} \mathrm{C}\right)$ under $1000 \mu \mathrm{mol}$ quanta $\mathrm{m}^{-2} \mathrm{~s}^{-1}$ artificial light. Light was provided by Aqua-starlight ${ }^{\circledR}$ aquaria lights fitted with metal-halide bulbs (Ab aqua- line). During these experiments, a subset of corals were also exposed to light and temperature stress as individual stressors. In the low stress (LS) treatment, corals were exposed for $5 \mathrm{~d}$ to $31^{\circ} \mathrm{C}\left( \pm 1^{\circ} \mathrm{C}\right)$ under $500 \mu \mathrm{mol}$ quanta $\mathrm{m}^{-2} \mathrm{~s}^{-1}$ artificial light $(10: 14 \mathrm{~h}$, L:D cycle). During both the HS and LS experiments, control explants were exposed to $26^{\circ} \mathrm{C}$ under $300 \mu \mathrm{mol}$ quanta $\mathrm{m}^{-2} \mathrm{~s}^{-1}$. Chlorophyll fluorescence measurements, cell staining, and light microscopy was conducted on algae extracted from these corals throughout the duration of the experimental treatments. Survivorship of corals after the HS and LS treatments was monitored for approximately 1 mo when corals were returned to baseline conditions (maximum 300 to $400 \mu \mathrm{mol}$ quanta $\mathrm{m}^{-2} \mathrm{~s}^{-1} \mathrm{PAR}$ and 25 to $27^{\circ} \mathrm{C}$ ).

To examine the condition of algae expelled from Stylophora pistillata, corals were exposed to a combination of elevated temperature and artificial light in individual containers holding $450 \mathrm{ml}$ of GF/C filtered (pore size $1.2 \mu \mathrm{m}$ ), aerated seawater. In these experiments, temperatures ranged from 30 to $34^{\circ} \mathrm{C}$ (i.e. a diel range), and PAR was approximately $1000( \pm 200) \mu \mathrm{mol}$ quanta $\mathrm{m}^{-2} \mathrm{~s}^{-1}$, depending on the randomised location in the tank. Filtered seawater was replaced at the beginning and end of the light period and expelled dinoflagellates were collected via centrifugation $(6700 \times g$ for $\sim 6 \mathrm{~min}$ ). Experiments were conducted over a $4 \mathrm{~d}$ period. For all treatments, baseline and experimental conditions are summarised in Table 1. Experiments were conducted in the summers of 2001 and 2002. In 2002, reef flat temperatures were higher (there was a mass bleaching event at this time), and so baseline and experimental conditions were elevated relative to the previous year.

During a natural coral bleaching event at Heron Island in the summer of 2001/2002 (see 'Results'), branches of Stylophora pistillata were collected from the reef flat and transported back to the HIRS aquarium facility. Branches were collected from colonies

Table 1. Summary of light and temperature treatments applied to Stylophora pistillata explants at Heron Island Research Station (HIRS) and University of Queensland (UQ) between January 2001 and March 2002. Higher light and temperature conditions were used during summer 2002 when sea surface temperatures were higher (see 'Materials and methods')

\begin{tabular}{|c|c|c|}
\hline Treatment and location/date & Baseline conditions, tank type & $\begin{array}{l}\text { Stress conditions, maximum duration of } \\
\text { exposure, tank type }\end{array}$ \\
\hline High stress, HS (UQ 2001) & $\begin{array}{l}26^{\circ} \mathrm{C}, 300 \mu \mathrm{mol} \mathrm{m}{ }^{-2} \mathrm{~s}^{-1} \\
\text { Closed aquarium, artificial light }\end{array}$ & $\begin{array}{l}32^{\circ} \mathrm{C}, 1000 \mu \mathrm{mol} \mathrm{m}{ }^{-2} \mathrm{~s}^{-1}, 8 \mathrm{~h} \\
\text { Closed aquarium, artificial light }\end{array}$ \\
\hline Low stress, LS (UQ 2001) & $\begin{array}{l}26^{\circ} \mathrm{C}_{,} 300 \mu \mathrm{mol} \mathrm{m}{ }^{-2} \mathrm{~s}^{-1} \\
\text { Closed aquarium, artificial light }\end{array}$ & $\begin{array}{l}31^{\circ} \mathrm{C}, 550 \mu \mathrm{mol} \mathrm{m}{ }^{-2} \mathrm{~s}^{-1}, 5 \mathrm{~d} \\
\text { Closed aquarium, artificial light }\end{array}$ \\
\hline Expulsion (HIRS 2002) & $\begin{array}{l}29-32^{\circ} \mathrm{C}, 350 \mu \mathrm{mol} \mathrm{m}{ }^{-2} \mathrm{~s}^{-1} \\
\text { Flow-through aquarium, natural light }\end{array}$ & $\begin{array}{l}30-34^{\circ} \mathrm{C}, 1000 \mu \mathrm{mol} \mathrm{m}^{-2} \mathrm{~s}^{-1}, 4 \mathrm{~d} \\
\text { Flow-through aquarium, artificial light }\end{array}$ \\
\hline $\begin{array}{l}\text { Bleaching for electron microscopy } \\
\text { observations (HIRS 2002) }\end{array}$ & $\begin{array}{l}29-32^{\circ} \mathrm{C}, 350 \mu \mathrm{mol} \mathrm{m}{ }^{-2} \mathrm{~s}^{-1} \\
\text { Flow-through aquarium, natural light }\end{array}$ & $\begin{array}{l}30-33^{\circ} \mathrm{C}, 850 \mu \mathrm{mol} \mathrm{m}{ }^{-2} \mathrm{~s}^{-1}, 8 \mathrm{~d} \\
\text { Flow-through aquarium, artificial light }\end{array}$ \\
\hline
\end{tabular}


which were in semi-shaded positions and which still retained some pigmentation. Corals were maintained in flowing seawater which was drawn directly from a water intake at 5 to $6 \mathrm{~m}$ depth adjacent to the reef flat, and were shaded under neutral-density shade-cloth which reduced the irradiance intensity by approximately $80 \%$ of ambient. The maximum light intensites experienced by the corals was typically between 300 and $400 \mu \mathrm{mol}$ quanta $\mathrm{m}^{-2} \mathrm{~s}^{-1}$ at solar noon. Explants were randomly sampled over a $17 \mathrm{~d}$ period and the \% of Sytox-labelled algae in symbio was measured (see later subsection).

Chlorophyll fluorescence techniques. A pulse amplitude modulated (PAM) chlorophyll fluorometer (Diving-PAM, Walz) was used to assess the maximum potential quantum yield $\left(F_{\mathrm{v}} / F_{\mathrm{m}}\right)$ of the symbiotic algae in symbio, using the procedures and instrumental settings outlined in Jones \& Hoegh-Guldberg (2001). In the LS treatment, measurements were taken in the morning (just prior to the lights being turned on), mid-way through the $10 \mathrm{~h}$ illumination period, and in the evening $2 \mathrm{~h}$ after the lights were turned off.

Symbiont extraction and cell staining. Tissues were stripped from the coral skeleton using a jet of recirculated GF/F filtered seawater (Waterpik ${ }^{\mathrm{TM}}$, Technologies). The resulting coral suspension was centrifuged at $1800 \times g$ for $\sim 6 \mathrm{~min}$, and the pellet was resuspended in 1 to $5 \mathrm{ml}$ of filtered seawater.

Sytox-green (Sytox, Molecular Probes, Catalogue No. S-7020) is a mortal stain which tests the integrity of the plasma membrane, staining the nucleus a brilliant green in cells with a compromised membrane (Veldhuis et al. 2001). 2', 7'-dichlorodihydrofluorescein diacetate $\left(\mathrm{H}_{2} \mathrm{DCFDA}\right.$, Molecular Probes Catalogue No. D399) detects changes in the oxidative state of cells (Royall \& Ischiropoulos 1993, Malanga \& Puntarulo 1995), and was applied directly to extracted dinoflagellates. $\mathrm{H}_{2} \mathrm{DCFDA}$ diffuses into cells where intracellular esterases cleave off the diacetate group. This makes the molecule polar, which is thought to promote retention in the cell. Esterase cleavage results in $\mathrm{H}_{2} \mathrm{DCF}$ which is oxidised to DCF in proportion to the concentration of $\mathrm{H}_{2} \mathrm{O}_{2}$ (Collen \& Davison 1997) and hydroxyl radicals (Zhu et al. 1994) within the cell. Thus, changes in $\mathrm{H}_{2}$ DCFDA oxidation are thought to reflect an overall change in oxidant formation (Royall \& Ischiropoulos 1993).

Sytox was added to the homogenate to a final concentration of $5 \mu \mathrm{M}$ and incubated at $20^{\circ} \mathrm{C}$, in the dark, for at least $30 \mathrm{~min}$. Preliminary experiments showed that Sytox fluorescence was stable when applied at between 5 to $20 \mu \mathrm{M}$ after an incubation of greater than $25 \mathrm{~min}$. In a number of experiments, the vital stain fluorescein diacetate (FDA, Molecular Probes Catalogue No. F-1303), was added to a separate $1 \mathrm{ml}$ sample of the coral homogenate and incubated with a final concentration of $5 \mu \mathrm{M} F D A$, in the dark at $20^{\circ} \mathrm{C}$, for $1 \mathrm{~h}$. $\mathrm{H}_{2}$ DCFDA was added to a separate $1 \mathrm{ml}$ homogenate to a final concentration of $5 \mu \mathrm{M}$, and incubated as described above, for 30 min. FDA and $\mathrm{H}_{2}$ DCFDA were reconstituted in DMSO to make stock solutions (which were kept frozen and used for a maximum of $2 \mathrm{~d}$ ), and working stocks were daily made by secondary dilution in $50 \mathrm{mM}$ Tris buffer ( $\mathrm{pH}$ 7.5). After incubation with the stain, $150 \mu \mathrm{l}$ of each homogenate was injected into a haemocytometer and 400 to 500 dinoflagellate cells were scored for uptake of the respective probes by epifluorescence microscopy using wide-band blue excitation (for Sytox and FDA). As a positive control for the Sytox and FDA stains, dinoflagellates were collected from corals exposed to $70^{\circ} \mathrm{C}$ for $2 \mathrm{~h}$.

For $\mathrm{H}_{2}$ DCFDA staining, the total algae per field of view was counted using chlorophyll autofluorescence (i.e. using green excitation at 540 to $552 \mathrm{~nm}$ and emission $>590 \mathrm{~nm}$ ). The number of cells showing intra-cellular green fluorescence (DCF accumulation) when excited with blue light (excitation 450 to $490 \mathrm{~nm}$, emission 515 to $565 \mathrm{~nm}$ ) was also recorded and these data were used to calculate \% of DCF-positive cells. When cells were viewed with a wide emission filter, i.e. one that allowed red chlorophyll autofluorescence through, the weakness of DCF fluorescence made it difficult to accurately assess the cellular accumulation of DCF. The use of a band-pass emission filter (515 to $565 \mathrm{~nm}$ ) made direct viewing of DCF possible. In preliminary experiments, a positive control treatment of exposure to exogenous $\mathrm{H}_{2} \mathrm{O}_{2}$ (up to $50 \mathrm{mM}$ ) confirmed that the oxidation step of $\mathrm{H}_{2} \mathrm{DCF}$ to DCF could be mediated by $\mathrm{H}_{2} \mathrm{O}_{2}$. However, other oxidants can also mediate this step (see above, and 'Discussion').

Transmission electron microscopy (TEM). Corals were homogenised with a Waterpik ${ }^{\mathrm{TM}}$ and the resulting homogenate was concentrated by centrifugation $(1800 \times g, 6 \mathrm{~min}$; then $3000 \times g, 5 \mathrm{~min})$ and then fixed for $1 \mathrm{~h}$ in $100 \mathrm{mM} \mathrm{Na}$-cacodylate buffer containing $3 \%$ glutaraldehyde and $3 \%$ sucrose. Pellets were then washed 3 times in $100 \mathrm{mM} \mathrm{Na}$-cacodylate buffer with $3 \%$ sucrose and post-fixed in $\mathrm{OsO}_{4}$ for $1 \mathrm{~h}$. The pellet was then washed 3 times in $100 \mathrm{mM}$ Na-cacodylate buffer and stored at $4^{\circ} \mathrm{C}$ for approximately 2 mo before analysis. Following fixation, pellets were dehydrated in an ascending series of ethanol (70 to $100 \%$ ) and embedded in epoxy resin (Agar Scientific). The resin was then polymerised for $48 \mathrm{~h}$ at $60^{\circ} \mathrm{C}$ and sections of 60 to $100 \mathrm{~nm}$ were cut with a diamond knife on an ultramicrotome. These sections were collected on a copper grid and stained with uranyl acetate (15 min) before being washed in $50 \%$ ethanol and then with doubledistilled water. Grids were stained with lead citrate for $10 \mathrm{~min}$ and then washed with double-distilled water. 
Grids were viewed with a Phillips (CM 100) transmission electron microscope. All dinoflagellates on the grids were viewed and observations were pooled to generate a qualitative impression of symbiont ultrastructure. Approximately 100 to 200 sectioned dinoflagellates from each bleaching treatment were viewed and scored. Identification of organelle structures followed Dodge (1973). Dinoflagellates from corals collected from the reef flat, and also from those kept under baseline conditions, were examined as ultrastructure controls for the artificial bleaching treatments. Samples of 2 other reef-flat species, Acropora sp. and Pocillopora damicornis, were also examined at this time.

\section{RESULTS}

\section{Chlorophyll fluorescence}

In the HS treatment, $F_{\mathrm{v}} / F_{\mathrm{m}}$ decreased from 0.65 to $<0.1$ during the $8 \mathrm{~h}$ monitoring period, indicating a complete photoinactivation of the PSII reaction centres (Fig. 1 inset). $F_{\mathrm{v}} / F_{\mathrm{m}}$ in control explants showed a consistent values of 0.6 to 0.7 (Fig. 1), with no significant relationship with time (linear regression; $\mathrm{p}>0.05$ ). In the LS treatment, $F_{\mathrm{v}} / F_{\mathrm{m}}$ measured at the middle of the light period decreased significantly (linear regression; $\mathrm{p}<0.05$ ) from 0.7 to 0.45 over the $5 \mathrm{~d}$ monitoring period (Fig. 1). In the first $2 \mathrm{~d}$ of the experiment, $F_{\mathrm{v}} / F_{\mathrm{m}}$ in the

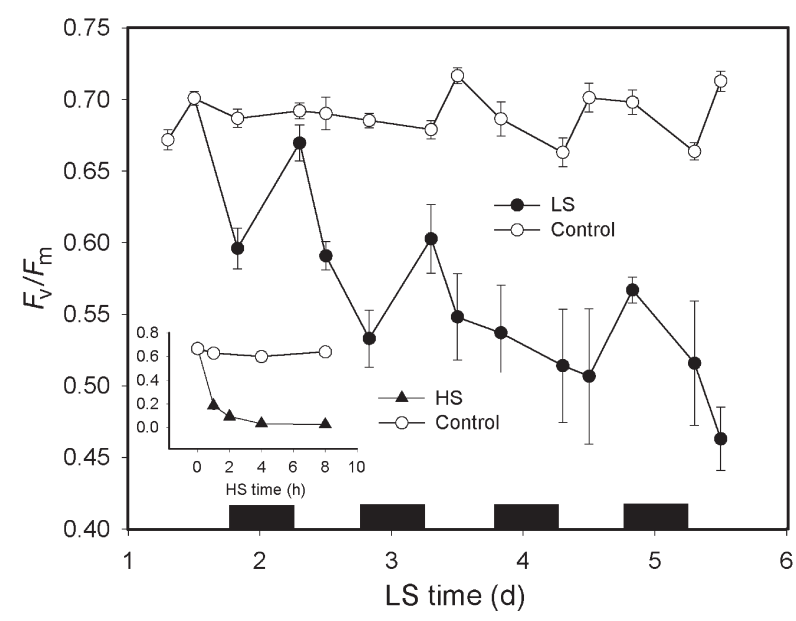

Fig. 1. Symbiodinium sp. Maximum potential quantum yield of photosynthesis (dark-adapted $F_{\mathrm{V}} / F_{\mathrm{M}}$ ) in dinoflagellates in the coral Stylophora pistillata exposed to elevated light and temperature. (•) Corals kept in low-stress (LS) treatment (see 'Materials and methods'); (O) control readings (unstressed). Inset: corals kept in the high-stress (HS) treatment (₫) with control readings (O). Black bars represent the dark period. LS data are mean \pm 1 SEM, $\mathrm{n}=18$ explants, declining to 5 explants (last reading) as corals were used for staining and morphological examination; HS data are mean \pm 1 SEM, $n=2$ explants. Note different time units on $x$-axes evening was lower than on the morning of the next day, indicating a partial recovery overnight. The overnight recovery in yield was statistically significant for the first $2 \mathrm{~d}$ (Mann-Whitney $U$-test; $\mathrm{p}<0.05$ ). However, this pattern was lost after Day 2, after which there was a general decline in $F_{\mathrm{v}} / F_{\mathrm{m}}$ with time.

\section{Stain-labelling and survivorship of corals}

Sytox-green passed across degraded dinoflagellate plasma membranes, where it clearly labelled the nucleus (Fig. 2A). $\mathrm{H}_{2}$ DCFDA staining was less localised, with stain fluorescence seen throughout the cell (Fig. 2B). Negative controls (no $\mathrm{H}_{2}$ DCFDA stain) indicated that no autofluorescence originated from the dinoflagellate cell in the narrow emission channel ( 515 to $565 \mathrm{~nm}$ ) used to visualise the stain fluorescence (data not shown). Control samples incubated with FDA showed an opposite trend to $\mathrm{H}_{2}$ DCFDA with increasing exposure to stress (data not shown), thereby discounting the possibility that DCF fluorescence was the result of simple esterase activity. Because of this, we concluded that stain fluorescence was due to DCF produced in the presence of oxidants. In positive controls, i.e. corals exposed to $70^{\circ} \mathrm{C}$ for $2 \mathrm{~h}, 90 \%$ of the population labelled positively with Sytox-green, and fixation with formaldehyde overnight gave $86 \%$ labelling (data not shown). In corals kept under baseline (unstressed) conditions, the number of Sytox-labelled cells was typically $<10 \%$ of the total (Fig. 2C,D). In corals exposed to elevated light alone (i.e. exposed to a maximum of $1000 \mu \mathrm{mol}$ quanta $\mathrm{m}^{-2} \mathrm{~s}^{-1} \mathrm{PAR}$ at $\left.26^{\circ} \mathrm{C}\right), 6 \%$ of the symbiotic dinoflagellates were Sytox-labelled. In corals exposed to elevated temperature alone $\left(31^{\circ} \mathrm{C}\right.$ under $350 \mu \mathrm{mol}$ quanta $\left.\mathrm{m}^{-2} \mathrm{~s}^{-1} \mathrm{PAR}\right), 13 \%$ of the algae cells were Sytox-labelled; data not shown). These stressors were combined into the HS treatment (Fig. 2C), where the percentage of Sytox-labelled dinoflagellates increased significantly ( $<<0.05$, linear regression) over the $8 \mathrm{~h}$ monitoring period, from $<10 \%$ to a maximum of $60 \%$ of cells labelled. In the HS treatment, corals were fatally damaged within $2 \mathrm{~h}$. That is, if corals were in the high-stress treatment for more than $2 \mathrm{~h}$ then they never survived after being transferred back to holding conditions. After $8 \mathrm{~h}$ in the high-stress treatment, many corals showed tissue sloughing. Within this experiment, control explants analysed at random times throughout the day showed $<10 \%$ Sytox-labelling. In the LS treatment (Fig. 2D) the percentage of Sytoxlabelled dinoflagellates $(21 \%)$ was elevated in comparison with unstressed corals ( $~ 5 \%$ labelling, Fig. 2D). In the LS treatment, slight bleaching (pigment loss) was observed compared with unstressed corals during the $5 \mathrm{~d}$ exposure; however all corals bleached com- 

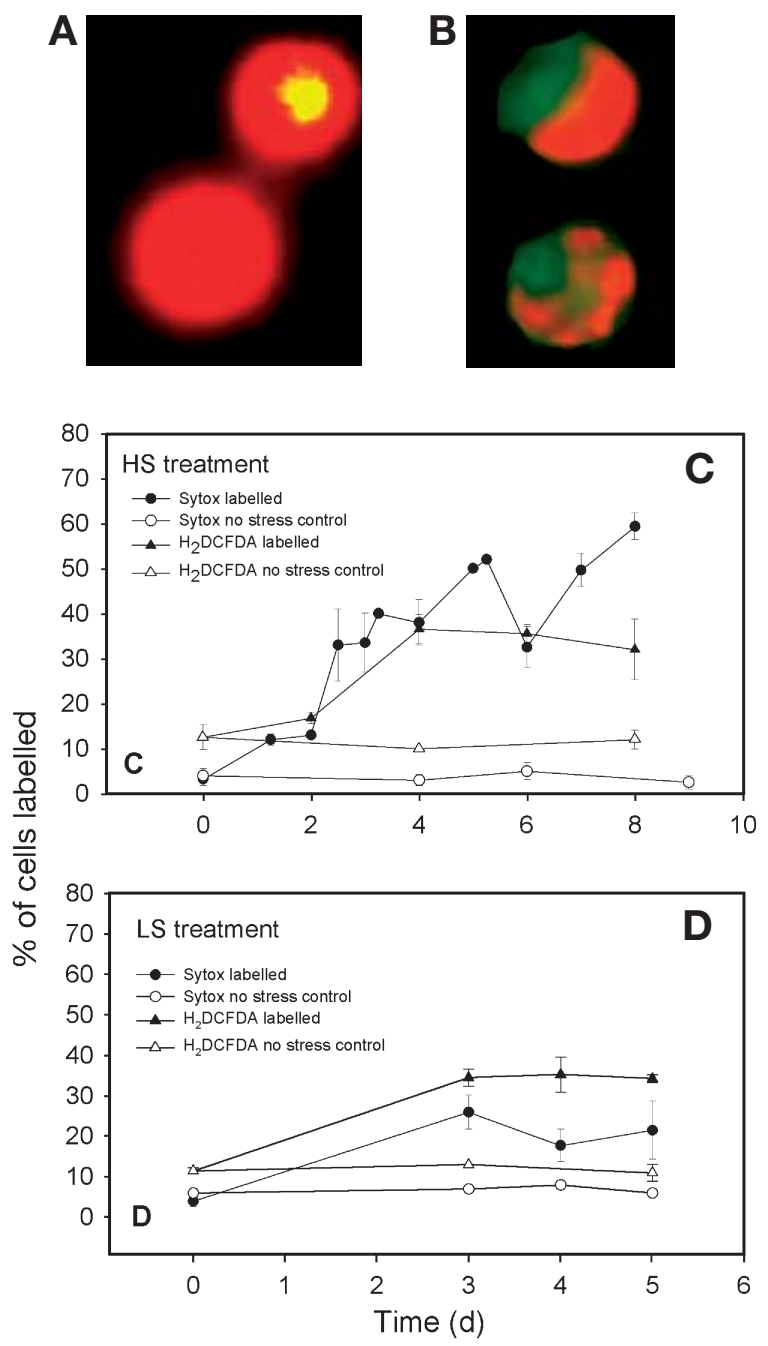

Fig. 2. Symbodinium sp. Sytox-green (A, membrane permeability) and $\mathrm{H}_{2}$ DCFDA (B, reactive oxygen species activity) staining in symbiotic dinoflagellates from Stylophora pistillata exposed to combination of elevated light and temperature. (C) HS treatment: Sytox-green staining $(\bullet)$ and controls (O), and $\mathrm{H}_{2}$ DCFDA staining $(\boldsymbol{\Delta})$ and controls $(\Delta)$; (D) LS treatment: Sytox-green staining $(\bullet)$ and controls $(O)$, and $\mathrm{H}_{2}$ DCFDA staining $(\boldsymbol{\Lambda})$ and controls $(\Delta)$. Note different $x$-axes between HS and LS treatments. All data are mean \pm 1 SEM, $\mathrm{n}=2$ explants

pletely during the subsequent monitoring period. After the LS treatment, corals either died within 3 to $4 \mathrm{~d}$ of being returned to the holding tank $(\mathrm{n}=3)$, or survived ( $\mathrm{n}=8$ ) with bone-white tissue and with poylps extruded and apparently feeding.

$\mathrm{H}_{2}$ DCFDA staining was performed with filter combinations which allowed direct visualisation of DCF. In the HS experiment, the number of DCF-positive (i.e. ROS-positive) dinoflagellate cells increased over the first $4 \mathrm{~h}$ of the experiment and then remained constant, with between 30 and $40 \%$ of cells showing ROS accumulation (Fig. 2C). In control corals, analysed at the beginning and end of the day, 10 to $15 \%$ of the algae cells were ROS-positive. The increase in ROS production under elevated light and temperature was significant (paired $t$-test; arcsine-transformed data; $\mathrm{p}<0.05$ ). In the LS experiment the pattern was broadly similar with corals showing an increase in DCF-labelled algae relative to controls (Fig. 2D). Control corals analysed for experimental artifacts (i.e. effects of handling and transferring corals between tanks) indicated no effects, and labelling of the algae symbionts was no different from that of corals kept in the control tank (data not shown).

Corals in the expulsion experiment bleached during the $4 \mathrm{~d}$ exposure period, preferentially discolouring in the coenosarc between the polpys, giving the coral a 'speckled' appearance. Symbiotic dinoflagellates expelled from the corals appeared chlorotic (i.e. lacking chlorophyll autofluoresence) under the epifluorescent microscope. Chlorotic cells formed between 29 and $88 \%$ of the expelled cell total (Fig. 3). Between 41 and $48 \%$ of the expelled algae labelled positive with Sytox-green (Fig. 3). Sytox-labelling was possible amongst chlorotic cells, although not all chlorotic cells were Sytox-labelled. Both corals in the expulsion experiment remined alive in a bleached state for 1 mo following the experiment.

\section{Dinoflagellate morphology}

In the HS treatment, dinoflagellate vacuolisation (which may represent either a loss of intracellular contents, protoplast shrinkage, or both) was apparent under the light microscope (Fig. 4A). In contrast,

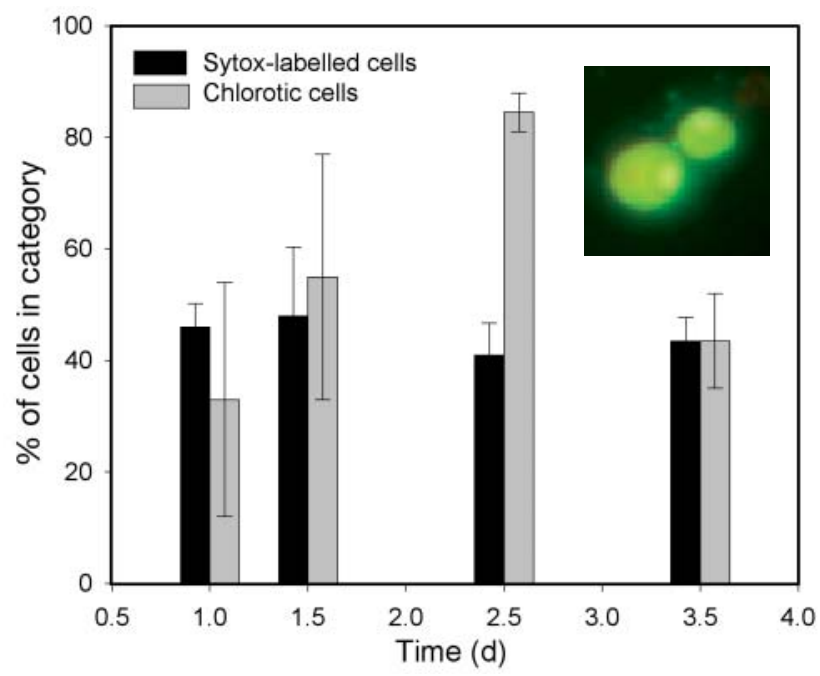

Fig. 3. Symbiodinium sp. Condition of expelled dinoflagellates during bleaching of coral Stylophora pistillata. Expelled cells were characterised as either chlorotic (lacking pigment autofluorescence) or Sytox-labelled. Inset: appearance of chlorotic cells under epifluorescence microscopy (see 'Materials and methods') 

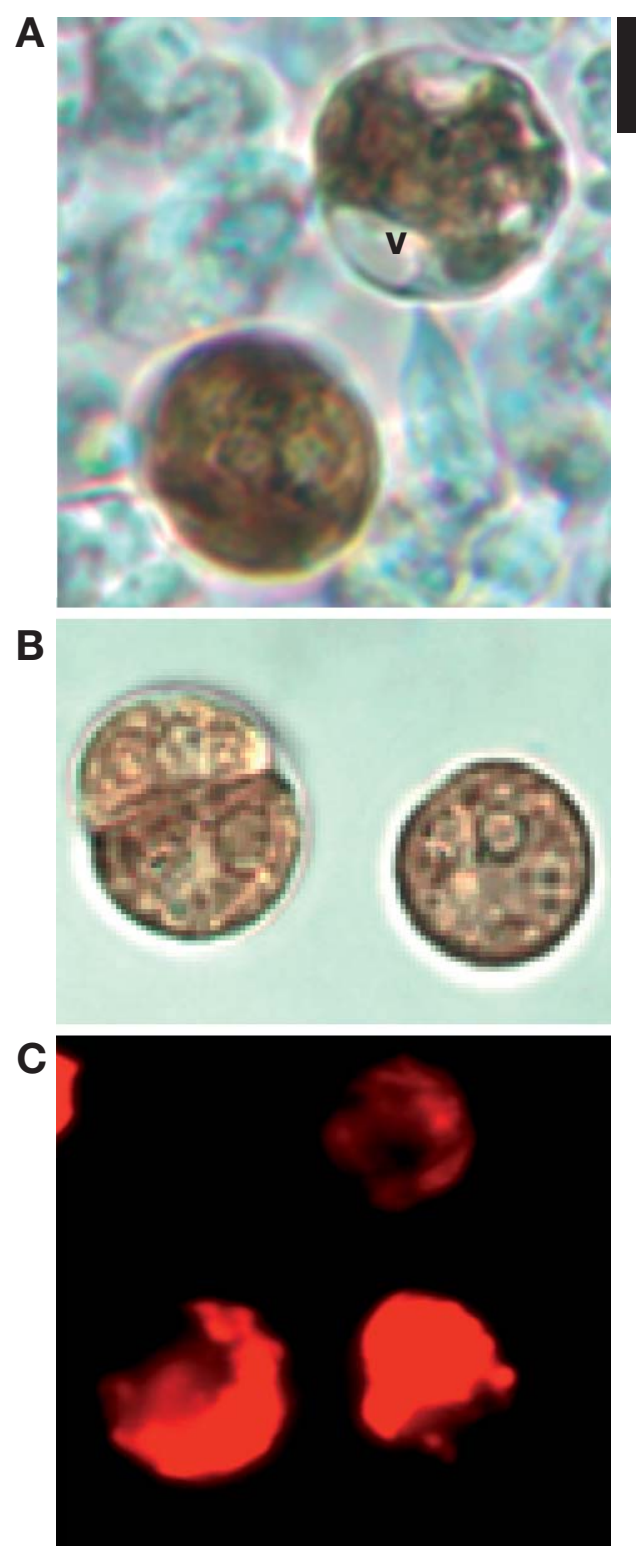

Fig. 4. Symbiodinium sp. Morphology of dinoflagellate symbionts under artificial bleaching stress. (A) Cells after $2-3 \mathrm{~h}$ in high-stress treatment ( $\mathrm{v}=$ vacuolated region [see 'Results']); (B) cells from low-stress treatment in which vacuolisation was not observed (note dividing cell on left); (C) cells from highstress treatment under green excitation: loss of pigment autofluorescence was associated with vacuolisation in (A). Scale bar is approximately $10 \mu \mathrm{m}$

dinoflagellates from the LS treatment appeared no different from dinoflagellates extracted from unstressed coral (Fig. 4B). Under the epifluorescence microscope, dinoflagellate chlorophyll autofluorescence in HS cells was reduced, associated with vacuolisation of cell contents (Fig. 4C). Under TEM, dinoflagellates from the LS treatment showed clear signs of degradation, whilst those from the reef flat (used as controls for the stress treatments) were densely packed, studded with numerous starch grains, and contained prominent pyrenoids. Chloroplast thylakoids were stacked, and often arranged around the periphery of the cell. The accumulation body was usually present as a single, large entity within the cell (Fig. 5A). (Please note that the micrograph in Fig. 5A was from an unstressed Acropora sp. symbiont and is presented here simply as a guide to the appearance of unstressed symbionts.)

Dinoflagellates from $3 \mathrm{~d}$ bleached Stylophora pistillata (Fig. 5B,C) may have had increased lipid within the cells, although many were not qualitatively different from reef flat algal symbionts. After $8 \mathrm{~d}$ of artificial bleaching treatment (Fig. 5D-H), symbiont appearance was more variable: dinoflagellates showed increased vacuolisation and disorganised, loosened thylakoids. The major difference between $8 \mathrm{~d}$ bleached cells and reef flat symbionts was the proliferation, or separation, of the accumulation body into numerous bodies throughout the cell (Fig. 5D,E). In general, lipid droplets, and accumulation bodies, appeared more prominent under artificial bleaching, though this was not quantified.

Expelled dinoflagellates lacked intracellular structure, and amorphous, membraneous material and multiple accumulation bodies were the only recognisable cell contents (Fig. 5I-L). Ultrastructural observations are summarised in Table 2.

\section{Symbiotic dinoflagellate cell death during natural bleaching event of February 2002}

The number of Sytox-labelled cells in naturally bleached corals increased from 2 to $22 \%$ over the first $9 \mathrm{~d}$ of the monitoring period, before dropping to less than $5 \%$ on the 18th (and final) day of monitoring (Fig. 6). Over the $18 \mathrm{~d}$ monitoring period, symbiotic dinoflagellate death did not correlate significantly with sea temperature $(p>0.05)$. Sea temperatures reached their highest levels of the summer $\left(34.6^{\circ} \mathrm{C}\right.$ on 8 February) during the monitoring period. Fig. 6 inset shows the daily temperature range over the first 3 mo of 2002, and the highest temperature is marked by a line. Widespread coral bleaching and mortality occurred on the reef flat at this time (Dennis 2002).

\section{DISCUSSION}

\section{Chlorophyll fluorescence}

Recent diel studies of chlorophyll fluorescence in corals have indicated that the symbiotic algae of coral routinely experience short-term photoprotective down- 

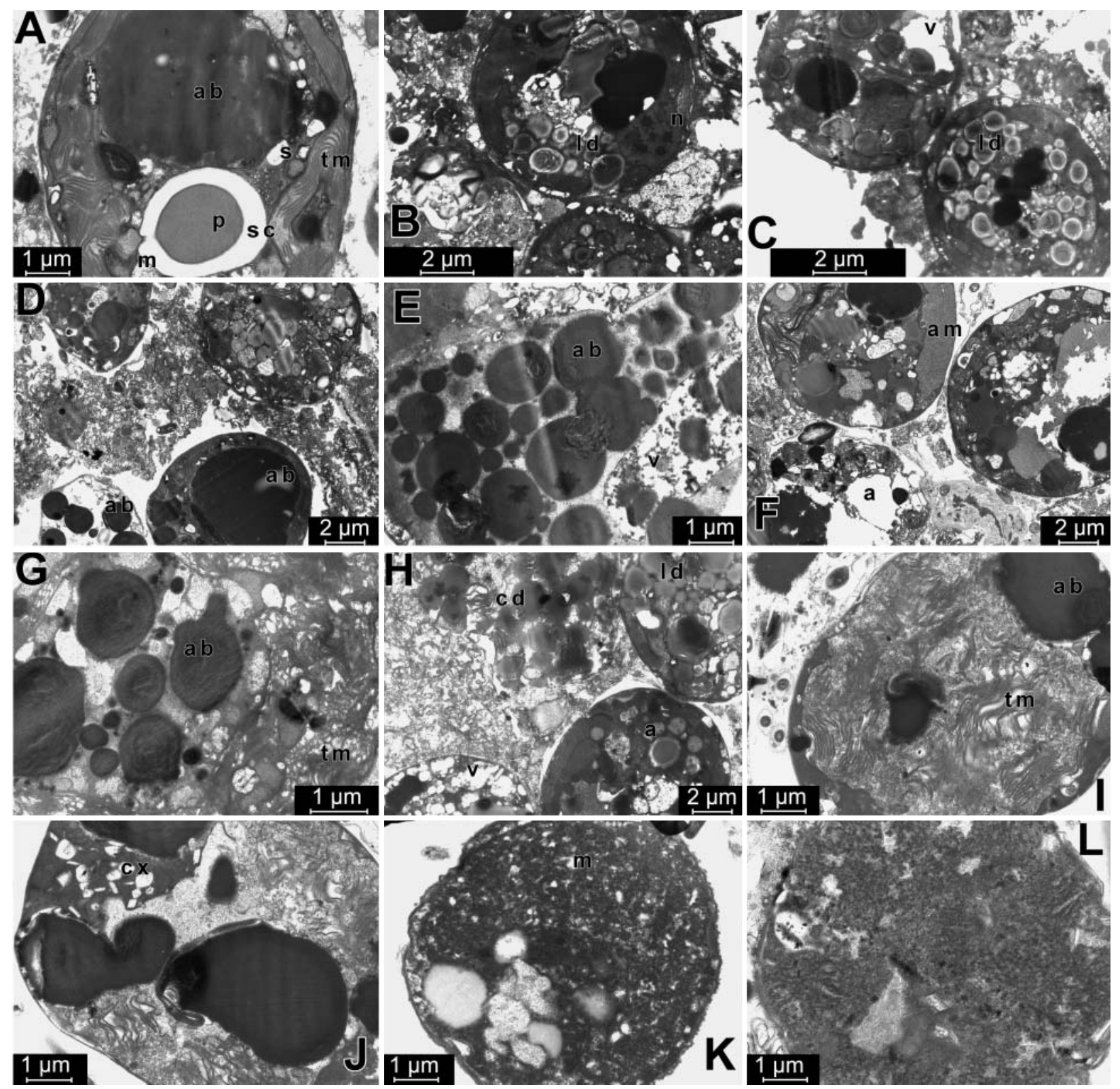

Fig. 5. Symbiodinium sp. Ultrastructure of symbionts. (A) Unstressed symbiont extracted from reef flat Acropora sp. at Heron Island (Australia): accumulation body (ab) is prominent in this section, also visible are thylakoid membranes (tm) around periphery of cell and pyrenoid (p), encased in a starch-cap (sc); a mitochondrion (m) abuts the starch cap and starch grains (s) are also studded throughout the cell. $(\mathrm{B}, \mathrm{C})$ Ultrastructure of symbionts from coral Stylophora pistillata after $3 \mathrm{~d}$ artificial bleaching: (B) lipid droplets (ld) are prominent throughout lower cell, and nucleus (n) is also visible in this cell. (C) significant accumulations of lipid (ld) can be seen in right-hand cell, and neighbouring cell shows some vacuolisation (v). (D-H) Degeneration amongst symbionts extracted from the $S$. pistillata exposed to $8 \mathrm{~d}$ of artificial bleaching stress. (D) Large accumulation body (ab) is prominent in one of the symbionts, and numerous smaller accumulation bodies are present in neighbouring symbiont that has lost all other internal structure; lipid droplets, accumulation bodies, starch grains and vacuoles are present in the 2 other symbionts; (E) numerous electron-dense accumulation bodies ( $a b$; see 'Results') permeate symbiont, vacuoles (v) are also present; (F) severe vacuolisation in symbiont accompanied by disorganisation of cell contents (a), formation of amorphous material (am) is visible within another symbiont; $(\mathrm{G}, \mathrm{H})$ after $8 \mathrm{~d}$ artificial bleaching $(\mathrm{G})$ multiple accumulation bodies $(\mathrm{ab})$ are visible within cell with disorganised (loosened) thylakoid membranes (tm), and (H) lipid accumulation (ld) and severe vacuolisation (v) in symbionts beside a symbiont (a) that has relatively healthy appearance, cellular debris (cd), possibly algae in origin, is visible at top of this section. (I-L) Ultrastructure of symbiotic dinoflagellates expelled from coral $S$. pistillata: (I) in this section the only cell components visible are accumulation bodies (ab) and loosened thylakoid membranes (tm); (J) a similar cell to (I) with possibly an accumulation of calcium oxalate $(\mathrm{cx})$ in one part of the cell; $(\mathrm{K})$ degenerate symbiont packed with amorphous membranous material $(\mathrm{m})$;

(L) degenerate cell with no recognisable cell contents. Scale is given at side of each image (see Table 2 for summary) 
Table 2. Qualitative summary of ultrastructural observations made on symbiotic dinoflagellates from the coral Stylophora pistillata (see Fig. 5) collected from the Heron Island reef flat and from corals transferred to artificially elevated light and temperature conditions (see Table 1). Symbiotic dinoflagellates from the closely related corals Pocillopora damicornis and Acropora sp., collected from the reef flat, were also examined; in these corals dinoflagellate cell ultrastructure was not qualitatively different from $S$. pistillata dinoflagellate symbionts

\begin{tabular}{|c|c|c|}
\hline Treatment & Observations & Conclusions \\
\hline $\begin{array}{l}\text { None: coral collected from } \\
\text { reef flat }\end{array}$ & $\begin{array}{l}\text { Structures seen included interphase nuclei, pyrenoids, } \\
\text { accumulation bodies (typically } 1 \text { per cell), thylakoids, } \\
\text { mitochondria, starch grains, lipid droplets }\end{array}$ & $\begin{array}{l}\text { Vast majority of cells show a full } \\
\text { organelle complement, i.e. normal } \\
\text { appearance (sensu Dodge 1973) }\end{array}$ \\
\hline $3 \mathrm{~d}$ in bleaching treatment & $\begin{array}{l}\text { Cell size more variable and cell outline possibly more } \\
\text { irregular, although some (half) of the cells were no } \\
\text { different from reef flat coral symbionts. Prominent } \\
\text { lipid in some cells }\end{array}$ & $\begin{array}{l}\text { Cell population becoming more } \\
\text { variable in appearance }\end{array}$ \\
\hline $8 \mathrm{~d}$ in bleaching treatment & $\begin{array}{l}\text { Accumulation bodies poliferating in some cells, cells } \\
\text { more irregular (size and shape) in appearance, vacuoles } \\
\text { prominent, loosened thylakoid membranes. A few cells } \\
\text { retain a normal appearance }\end{array}$ & $\begin{array}{l}\text { Highly variable cell population, many } \\
\text { degenerate cells }\end{array}$ \\
\hline Expelled symbionts & $\begin{array}{l}\text { Accumulation bodies and irregular membranous material. } \\
\text { Some calcium oxalate in some cells. No normal cells }\end{array}$ & $\begin{array}{l}\text { Cells uniform in appearance; all } \\
\text { cells are degenerate }\end{array}$ \\
\hline
\end{tabular}

regulation of photosynthesis in symbio, as do the majority of marine photoautotrophs (Hoegh-Guldberg \& Jones 1999, Gorbunov et al. 2001). There is some evidence for a longerlasting decrease in quantum yield in symbio synonymous with photodamage (Gorbunov et al. 2001, Jones \& Hoegh-Guldberg 2001), but since the quantum yield can recover overnight, photoinhibition does not become cumulative over successive days

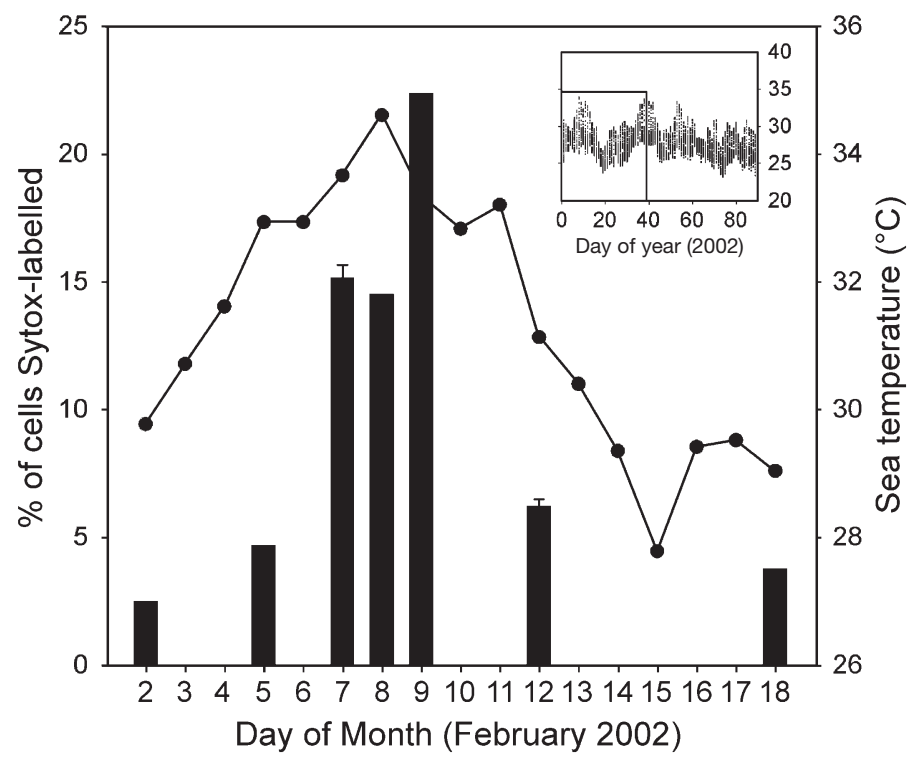

Fig. 6. Symbiodinium sp. In symbio Sytox-labelling of dinoflagellate symbionts during natural bleaching event on Heron Island Reef (Great Barrier Reef) during February 2002. Inset: sea temperatures between January and March 2002. Sea temperature shown is daily maximum in main graph, whereas inset shows daily range. Sytox-labelling observations not replicated except on 9 and 12 February, where they are mean $( \pm 1 \mathrm{SEM}, \mathrm{n}=2)$. Temperature data courtesy of Great Barrier Reef Marine Park Authority (Townsville, Australia)
(Hoegh-Guldberg \& Jones 1999, Gorbunov et al. 2001, Jones \& Hoegh-Guldberg 2001). In the photoinhibition model of coral bleaching (Jones et al. 1998) it was suggested that the balance of reversible photoprotective downregulation of algal photosynthesis is switched towards a more longer-term reduction in quantum yield synonymous with photodamage, and that this is the cue that initiates the dissociation of the symbiosis and subsequent discolouration of the coral (i.e. bleaching).

The data of this study support the photoinhibition model of bleaching. Previous studies with Stylophora pistillata (e.g. Jones \& Hoegh-Guldberg 2001) suggest that in response to high light, short-term protective down-regulation of photosynthesis is replaced with a more longer-term reduction in quantum yield synonymous with photodamage of the algal symbionts. Photoinhibition in the symbiotic algae of $S$. pistillata becomes cumulative over successive days if recovery is not complete overnight. Elevated temperature serves to increase the susceptibility of the algal symbionts to photoinhibition as photodamage. This has been well established, and of particular interest now are the morphological and cellular changes occurring in the algal symbionts as photodamage occurs.

There was a significant increase in the number of Sytox-labelled dinoflagellates in corals exposed to elevated light and temperature conditions. Sytox-labelling indicates a loss of plasma-membrane integrity, a cellular checkpoint in cell death (Veldhuis et al. 2001) that provides the basis for many fluorescence-based viability assays. In control corals, the number of Sytoxlabelled algae was approximately $\sim 5$ to $10 \%$ of the total, in agreement with previous workers who concluded that a low number of degenerate (dead) algae are a consistent feature of algal symbiont populations 
(Yonge \& Nicholls 1931, Fitt 1988, Gates \& Muscatine 1992). The effects of light and temperature were greatest when combined. In the HS treatment, dinoflagellate cell death correlated with stress duration, suggesting that algal cells were simply killed by the treatment, with no possibility for amelioration of the stress on the part of the algae. The intensity of the stress was similarly fatal for the host which, after $2 \mathrm{~h}$ of this treatment, could not subsequently survive. In the HS treatment, the individual effects of light and temperature were similar to controls (6 and 12\% Sytox-labelling), emphasizing a strong synergistic effect of light and temperature on dinoflagellate mortality. The LS treatment, in contrast, produced lower levels of dinoflagellate cell death coupled with greater host survival in a bleached state. Regeneration of dinoflagellate populations would most likely have been possible from the bleached state, although this is speculative. Given the potential of corals to survive the LS treatment, it is likely that the LS treatment caused a bleaching response similar to that which has occurred in mass bleaching events over the past 20 yr (e.g. Hoegh-Guldberg 1999). In this case, acclimatory responses on the part of the coral appeared to have occurred via the death and removal of dinoflagellates from the resident population. This is likely to have permitted the survival and persistence of the animal host.

Distinguishing between the 2 processes that our HS and LS treatments represented is important. The HS treatment was probably a poor simulation of the natural bleaching response. Data which has shown healthy symbionts appearing on the outside of the symbiosis during simulated bleaching (e.g. Ralph et al. 2001) may have limited explanatory power over the mechanism at work in natural bleaching events. The conclusion that expelled symbionts are photosynthetically competent (Ralph et al. 2001) differs from our results. Ralph et al. (2001) used a bleaching treatment of a $9 \mathrm{~h}$ exposure to an $8^{\circ} \mathrm{C}$ temperature rise $(25$ to $\left.33^{\circ} \mathrm{C}\right)$ under low light $\left(150 \mu \mathrm{mol} \mathrm{m} \mathrm{m}^{-2} \mathrm{~s}^{-1}\right)$. We suggest that such a treatment may not adequately simulate the time course, nor the temperature/light increases and interactions, typical of natural bleaching events (e.g. Jones 1997). We attempted to simulate natural bleaching with our LS treatment and the majority of our corals survived the bleaching we induced (as occurs in nature). We believe that it is important to attempt replication of the conditions which produce bleaching in nature when making observations that, by necessity, must be performed in the laboratory. In the experiments described by Ralph et al. (2001) the fate of the bleached corals is not given. This represents a hindrance in evaluating the ability of their conclusions to describe the processes involved in natural bleaching.

\section{Morphological changes}

Combining high light and high temperature (HS treatment) resulted in a total loss of variable chlorophyll fluorescence within 2 to $3 \mathrm{~h}$, indicating complete photoinactivation of the PSII reaction centres. Under such conditions, when excess light is present alongside inactivated PSII reaction centres, the generation of reactive oxygen species (ROS) is likely (Lesser 1997, Nishiyama et al. 2001), and ROS generation may therefore have caused the photooxidation of photosynthetic pigments - potentially explaining the changed appearance of symbionts under epifluorescence microscopy. Under similar conditions to those used here (i.e. an $8 \mathrm{~h}$ exposure, $\sim 1000 \mu \mathrm{mol}$ quanta $\mathrm{m}^{-2} \mathrm{~s}^{-1}, 32^{\circ} \mathrm{C}$ ) Salih et al. (1998) observed photooxidation of pigments and the rupture of the chloroplast envelope in symbionts extracted from Pocillopora damicornis. In this instance, photooxidation was accompanied by lipid accumulation (lipids formed into 'plastoglobuli'; Salih et al. 1998), as well as reductions in photosynthetic capacity and shrinkage of cell contents (Salih et al. 1998). Thylakoid membrane lipids are temperature-sensitive, and denaturation of PSII complexes may be caused by lipid phase changes at high temperatures (Berry \& Björkman 1980), leading to disruption of PSII function (Georgieva 1999). Such a mechanism is consistent with our results and those of Salih et al. (1998). However, the HS treatment which produced this effect caused host death within $2 \mathrm{~h}$, and is therefore a doubtful simulation of the majority of mass bleaching events, although in some parts of the world, e.g. Indian Ocean reefs, rapid host death has been observed when water temperatures reach levels high relative to long-term maxima (e.g. as in the 1998 mass bleaching event; Hoegh-Guldberg 1999).

In contrast, dinoflagellates exposed to the LS treatment did not display pigment reduction, or indeed any noticeable changes, under light microscopy in the $5 \mathrm{~d}$ monitoring period. Under TEM, and with an extended monitoring period (to $8 \mathrm{~d}$ ), some changes were observed (summarised in Table 2), although it should be stressed that our TEM observations were not quantitative. During TEM observations we noted that it could be relatively easy to confuse lipid and accumulation body material in dinoflagellate cells (both lack obvious surface features). Nevertheless, an increased prominence of the accumulation body was indicated by our TEM observations, in agreement with those of previous workers (e.g. Le Tissier \& Brown 1996).

The accumulation body is thought to be an autophagic structure responsible for the breakdown of surplus membranous structures and organelles into their basic components (Dodge 1973), and accumulation of osmiophilic granules in Euglena granulata (chloro- 
phyceae) is thought to indicate cell-aging, i.e. senescence (Palisano \& Wayne 1972). In the algae symbiont of the dinoflagellate Peridinium granulata, the consolidation of electron-dense osmiophilic globules (Tomas \& Cox 1973) represents the routine processing of waste materials. In Symbiodinium sp., accumulation body proliferation may be a cellular response to physiological stress because the number of accumulation bodies increases in response to high, and UV, light (Lesser \& Shick 1990). Conversely, in the free-living dinoflagellate Protogonyaulax sp., the number of accumulation bodies increases in response to low light conditions (Yentsch et al. 1985). The general inference from these studies is that dinoflagellate cells have an increased requirement for catabolic capacity under stress due to cell reorganisation/adaptation to changing conditions. However, if accumulation body proliferation leads to the total loss of all cell contents (Fig. 5D), or the loss of almost all recognisable structure (Fig. 5I-L), then it is difficult to ascribe an adaptive role to accumulation body activity. More likely, accumulation body proliferation represents the induction of 'autolytic' cell death (Trench 1974, 1987) amongst dinoflagellate symbionts, which is the routine manner of cell death (i.e. during cell turnover) within the symbiosis. The trigger or triggers for the induction of an autolytic pathway is not clear; it could be dependent on the algal cell integrating signals from within itself (e.g. oxidative stress, which would also increase with cell age) or, possibly, from the host. In this sense, cell death could be mediated by the algal cell itself. Such a self-mediated cell death is thought to be especially important in higher plant cells, since there are no macrophage or neutrophil cells to make the decision to die for the cell, i.e. by intercellular signalling (Jones 2001).

In the coral symbiosis, the capacity for algal cells to mediate their own cell death may allow the host to survive episodes of bleaching. Perhaps some feature of the dead dinoflagellate is recognised by the cnidarian which triggers expulsion. In the scyphistoma of Cassiopeia xamachana, poisoning of symbiont photosynthesis with 3-(3,4-dichlorophenyl)-1,1-dimethylurea (DCMU) triggers host phagocytosis, suggesting that reduction in photosynthate delivery may lead to symbiont loss (Fitt \& Trench 1983). The expelled cells in this study were certainly dead (Sytox-labelling) and almost certainly photosynthetically non-functional (they were chlorotic and had a degraded ultrastructure). The remains of dead and degraded algae cells probably provide little benefit to the host animal and therefore their expulsion follows their death. In this sense it appears that the coral acts very much like a monogenomic multicellular organism, with non-functional parts being excised for the greater good of the whole organism. The persistence of the accumulation body when almost all other intracellular structure has been lost (see Fig. 5I,J) strongly suggests that those dinoflagellate cells that have died and degenerated in hospite are the cells which are subsequently expelled.

Recently, a programmed cell death pathway (PCD) has been proposed to operate during bleaching: in the sea anemone Aiptasia sp., bleaching stress (increased temperature) causes the formation of 'electron dense, extracellular bodies derived from the budding of organelles within the condensed [dinoflagellate symbiont] cell' (Dunn et al. 2002). These bodies closely resemble the accumulation bodies encountered in our study. Since accumulation body proliferation occurred simultaneously with the degradation of algal symbiont intracellular structure, DNA fragmentation and cell shrinkage, support for the idea that bleaching stress induced dinoflagellate PCD was claimed because characters such as DNA fragmentation are associated with PCD in metazoan cells. The accumulation body may, therefore, be functionally equivalent to the apoptotic bodies formed during the PCD of metazoan cells (Dunn et al. 2002). The role of the dinoflagellate accumulation body is poorly understood. More research is needed on the role of this organelle, which may have functional similarities with plant lysosomes or with metazoan apoptotic bodies. Also, for dinoflagellate cell death to be classified as programmed, gene expression must be demonstrated-gene expression is a defining feature of PCD (Ameisen 2002) - and the use of protein synthesis inhibitors, or measurements of caspase activities, would be a logical next step. Caspases are a family of intracellular proteases responsible for mediating PCD, and if the rate of algal symbiont cell death within host tissue under bleaching stress was decreased by protein synthesis inhibitors, or was shown to be dependent on caspase activity, then this would provide support for the existence of PCD amongst those symbionts. However, delivery of protein synthesis inhibitors into a symbiotic system in such a way that effects are limited to one of the symbionts, is likely to be technically difficult.

\section{Contribution of photoinhibition and oxidative stress to dinoflagellate mortality and the possible role of carbon limitation}

Reductions in photosynthetic capacity (photoinhibition) and an increase in ROS within the algal symbiont correlate with cell death. Dissecting out the sequence of events induced by bleaching stress and the role of oxidative stress at the molecular scale remains a significant challenge. During bleaching stress, overreduction of the electron transport chain downstream of the PSII reaction centre is hypothesised to cause a 
build-up of ROS, principally as superoxide anion $\left(\mathrm{O}_{2}^{-}\right)$ (Jones et al. 1998). In this study, the increase in $\mathrm{H}_{2}$ DCFDA oxidation under bleaching conditions (in both high- and low-stress experiments) indicates a general intracellular increase in oxidant formation (Royall \& Ischiropoulos 1993). $\mathrm{H}_{2}$ DCFDA is known to be oxidised by $\mathrm{H}_{2} \mathrm{O}_{2}$ in the presence of peroxidases and also by the hydroxyl radical generated via the Fenton reaction (Collen \& Davison 1997, Lesser 1997). The superoxide anion $\left(\mathrm{O}_{2}^{-}\right)$does not oxidise $\mathrm{H}_{2}$ DCFDA (Zhu et al. 1994). On this basis, our data cannot support the idea that the superoxide anion $\left(\mathrm{O}_{2}^{-}\right)$is the principal ROS accumulated within the algal symbiont cell under photoinhibitory conditions: other ROS, e.g. $\mathrm{H}_{2} \mathrm{O}_{2}$ or hydroxyl radicals, may cause the oxidative damage (Lesser 1996) thought to be associated with photoinhibitory conditions.

The general involvement of ROS in cell death is well known (e.g. Jabs et al. 1996), as is the propensity of the chloroplast to produce ROS under heat stress (Asada et al. 1998). In plant cells, exogenous $\mathrm{H}_{2} \mathrm{O}_{2}$ is known to prompt specific gene expression which leads to cell death (and therefore the cell death is called programmed; Levine et al. 1994). The ability of coral antioxidants to defend against ROS damage has been experimentally tested by supplementing coral antioxidant capacity with antioxidants supplied in their seawater (e.g. ascorbate and catalase; Lesser 1997). Our study is the first to use mortal stains to quantify the death of algal symbionts in reef corals, and by using stains such as Sytox the link between oxidative stress and algal mortality can now be explicitly tested. Supplying corals with exogenous antioxidants and then quantifying their possible protective effects in reducing dinoflagellate mortality would help in establishing the link between oxidative stress, algal mortality and subsequent coral bleaching. Although host tissue antioxidants are important in ameliorating the bleaching response (Brown et al. 2002), the point at which both host and algal antioxidant capacity is overwhelmed is unclear.

Carbon (C) limitation has attracted attention as a possible contributor to oxidative stress in photosynthetic cells (Lesser 1997), and in the free-living dinoflagellate Peridinium gatunense $\mathrm{C}$ limitation is thought to stimulate ROS accumulation and subsequent cell death (Vardi et al. 1999). Symbiotic dinoflagellates may be especially susceptible to carbon limitation due to their high population densities within coral tissue (e.g. $1.5 \times 10^{5}$ symbionts polyp ${ }^{-1}$ [40 mm polyp, Acropora formosa; Jones 1997] which, due to symbiont photosynthesis, is usually supersaturated with oxygen (Lesser et al. 1990), and this, coupled with the poor $\mathrm{CO}_{2}$ specificity of dinoflagellate RUBISCO (Form II RUBISCO), may promote C limitation. Establishing a link between C limitation and ROS-mediated cell death is made difficult by the involvement of the host in carbon delivery. An active transepithelial mechanism is thought to deliver inorganic carbon to the symbiont (Allemand et al. 1997). The susceptibility of this mechanism to bleaching stress, and therefore its potential in causing $\mathrm{C}$ limitation, is not known (Dykens \& Schick 1982). C limitation in prokaryotes can quickly produce photooxidation and cell death under conditions otherwise favourable for photosynthesis (Eloff et al. 1976). The similarities between prokaryote cell death (e.g. loss of photosynthetic pigment, declines in photosynthetic activity) and symbiotic dinoflagellate cell death suggest that $C$ limitation may be important in causing ROS accumulation which may subsequently act as a trigger for cell death. Such a conclusion is strengthened by other features of coral which suggest that $\mathrm{C}$ limitation of the algal cell is important. The fixed morphology of pocilloporid corals may impose a flow regime that leads to inorganic carbon limitation (Lesser et al. 1994) through inadequate transfer of dissolved inorganic carbon. This idea is supported by the fact that lower flow regimes intensify temperatureinduced bleaching on reefs (Nakamura \& Van Woesik 2001), which may ultimately contribute to the differential patterns of survival between massive and branching forms in bleaching events (Loya et al. 2001).

\section{Conclusions}

We tested whether dinoflagellate cell death precedes bleaching in the coral Stylophora pistillata. Dinoflagellate symbiont cell death preceded bleaching of the coral, and for this reason symbiont cell death is likely to be one of the first steps of coral bleaching. Dinoflagellate cell death coincided with both depressed photosynthetic yield and increased intracellular oxidative stress (ROS accumulation), suggesting that ROS could act as a cell death trigger. Dinoflagellate cell death appeared similar to an autolytic form of cell death, i.e. intrinsic to the dinoflagellate cell (Trench 1974), which may have been mediated by accumulation body activity. The environmental conditions which cause bleaching therefore exceed the tolerances of dinoflagellate symbionts which leads to their death and, subsequently, coral bleaching.

Acknowledgements. We thank S. Thyer for help maintaining coral in aquaria, Dr. W. Loh for accommodation, Dr. T. Ridgeway for transport, G. McCartney for TEM assistance, and the professionalism of all the staff and students at the Heron Island Research Station and the Centre for Marine Studies (University of Queensland). D.J.F. was supported by a scholarship, as well as 2 fieldwork awards, from the Department of Education \& Learning (Northern Ireland Government). ARC 
grants (A10009205 and A10009109) to O.H.-G. also supported this work. Thanks to Radem S.L. and Dr. H. Mendoza Guzmán for computer support, and to Dr. E. B. Young for discussions on chlorophyll fluorescence. We thank the anonymous reviewers for their helpful comments.

\section{LITERATURE CITED}

Allemand D, Furla P, Benazet-Tambutte S (1997) Mechanisms of carbon acquisition for endosymbiont photosynthesis in Anthozoa. Can J Bot 76:925-941

Ameisen JC (2002) On the origin, evolution, and nature of programmed cell death: a timeline of four billion years. Cell Death Differ 9:367-393

Asada K, Endo T, Mano J, Miyake C (1998) Molecular mechanisms of relaxation and protection from light stress. In: Katoh K, Murata N (eds) Stress responses of photosynthetic organisms. Elsevier Science, Amsterdam, p 37-52

Berges JA, Falkowski PG (1998) Physiological stress and cell death in marine phytoplankton: induction of proteases in response to nitrogen or light limitation. Limnol Oceanogr 43:129-135

Berry J, Björkman O (1980) Photosynthetic response and adaptation to temperature in higher plants. Annu Rev Plant Physiol 31:491-543

Brown BE, Le Tissier MDA, Bythell JC (1995) Mechanisms of bleaching deduced from histological studies of reef corals sampled during a natural bleaching event. Mar Biol 122: 655-663

Brown BE, Downs CA, Dunne RP, Gibb SW (2002) Exploring the basis of thermotolerance in the reef coral Goniastrea aspera. Mar Ecol Prog Ser 242:119-129

Collen J, Davison IR (1997) In vivo measurement of active oxygen production in the brown alga Fucus evanescens using 2', 7'-dichlorohydrofluorescein diacetate. J Phycol 33:643-648

Dennis C (2002) Reef under threat from 'bleaching' outbreak. Nature 415:947

Dodge JD (1973) The fine structure of algal cells. Academic Press, London

Dunn SR, Bythell JC, Le Tissier MDA, Burnett WJ, Thomason JC (2002) Programmed cell death and cell necrosis activity during hyperthermic stress-induced bleaching of the sea anemone Aiptasia sp. J Exp Mar Biol Ecol 272:29-53

Dykens JA, Shick JM (1982) Oxygen production by endosymbiotic algae controls superoxide dismutase activity in their animal host. Nature 297:579-580

Dykens JA, Shick JM, Benoit C, Buettner GR, Winston GW (1992) Oxygen radical production in the sea anemone Anthopleura elegantissima and its endosymbiotic algae. J Exp Biol 168:219-241

Eloff JN, Steinitz Y, Shilo M (1976) Photooxidation of cyanobacteria in natural conditions. Appl Environ Microbiol 31: 119-126

Fitt WK (1988) Regulation of zooxanthellae in a marine hydroid. Endocyt Cell Res 5:111-131

Fitt WK, Trench RK (1983) Endocytosis of the symbiotic dinoflagellate Symbiodinium microadriaticum (Freudenthal) by endodermal cells of the scyphistomae of Cassiopeia xamachana and resistance of the algae to host digestion. J Cell Sci 64:195-212

Freudenthal HD (1962) Symbiodinium gen. nov. and Symbiodinium microadriaticum sp. nov., a zooxanthella: taxonomy, life cycle, and morphology. J Protozool 9:45-52

Gates RD, Muscatine L (1992) Three methods for isolating viable anthozoan endoderm cells with their intracellular symbiotic dinoflagellates. Coral Reefs 11:143-145

Georgieva K (1999) Some mechanisms of damage and acclimation of the photosynthetic apparatus due to high temperature. Bulg J Plant Physiol 25:89-99

Gorbunov MY, Kolber ZS, Lesser MP, Falkowski PG (2001) Photosynthesis and photoprotection in symbiotic corals. Limnol Oceanogr 46:75-85

Hoegh-Guldberg O (1999) Climate change, coral bleaching and the future of the world's coral reefs. Mar Freshw Res 50:839-866

Hoegh-Guldberg O, Jones RJ (1999) Photoinhibition and photoprotection in symbiotic dinoflagellates from reefbuilding corals. Mar Ecol Prog Ser 183:73-86

Hoegh-Guldberg O, Smith GJ (1989) The effect of sudden changes in temperature, light and salinity on the population density and export of zooxanthellae from the reef corals Stylophora pistillata Esper and Seriatopora hystrix Dana. J Exp Mar Biol Ecol 129:279-303

Iglesias-Prieto R, Trench RK (1997) Acclimation and adaptation to irradiance in symbiotic dinoflagellates. II. Response of chlorophyll-protein complexes to different photon-flux densities. Mar Biol 130:23-33

Jabs T, Dietrich RA, Dangl JL (1996) Initiation of runaway cell death in an Arabidopsis mutant by extracellular superoxide. Science 273:1853-1856

Jokiel PL, Coles SL (1977) Effects of temperature on the mortality and growth of Hawaiian reef corals. Mar Biol 43:201-208

Jones AM (2001) Programmed cell death in development and defense. Plant Physiol (Rockv) 125:94-97

Jones RJ (1997) Changes in zooxanthellar densities and chlorophyll concentrations in corals during and after a bleaching event. Mar Ecol Prog Ser 158:51-59

Jones RJ, Hoegh-Guldberg O (2001) Diurnal changes in the photochemical efficiency of the symbiotic dinoflagellates (Dinophyceae) of corals: photoprotection, photoinactivation, and the relationship to coral bleaching. Plant Cell Environ 24:89-99

Jones RJ, Hoegh-Guldberg O, Larkum AWD, Schreiber U (1998) Temperature-induced bleaching of corals begins with impairment of the $\mathrm{CO}_{2}$ fixation mechanism in zooxanthellae. Plant Cell Environ 21:1219-1230

Lesser MP (1996) Elevated temperatures und ultraviolet radiation cause oxidative stress and inhibit photosynthesis in symbiotic dinoflagellates. Limnol Oceanogr 41:271-283

Lesser MP (1997) Oxidative stress causes coral bleaching during exposure to elevated temperatures. Coral Reefs 16: 187-192

Lesser MP, Shick JM (1989) Effects of irradiance and ultraviolet radiation on photoadaptation in the zooxanthellae of Aiptasia pallida: primary production, photoinhibition, and enzymic defenses against oxygen toxicity. Mar Biol 102:243-255

Lesser MP, Shick JM (1990) Effects of visible and ultraviolet radiation on the ultrastructure of zooxanthellae (Symbiodinium sp.) in culture and in situ. Cell Tissue Res 261: 501-508

Lesser MP, Stochaj WR, Tapley DW, Shick JM (1990) Bleaching in coral reef anthozoans: effects of irradiance, ultraviolet radiation, and temperature on the activities of protective enzymes against active oxygen. Coral Reefs 8: 225-232

Lesser MP, Weis VM, Patterson MR, Jokiel PL (1994) Effects of morphology and water motion on carbon delivery and productivity in the reef coral, Pocillopora damicornis (Linnaeus): diffusion barriers, inorganic carbon limitation, 
and biochemical plasticity. J Exp Mar Biol Ecol 178: 153-179

Le Tissier MDA, Brown BE (1996) Dynamics of solar bleaching in the intertidal reef coral Goniastrea aspera at Koh Phuket, Thailand. Mar Ecol Prog Ser 136:235-244

Levine A, Tenhaken R, Dixon R, Lamb C (1994) $\mathrm{H}_{2} \mathrm{O}_{2}$ from the oxidative burst orchestrates the plant hypersensitive disease resistance response. Cell 79:583-593

Long SP, Humphries S, Falkowski PG (1994) Photoinhibition of photosynthesis in nature. Annu Rev Plant Physiol Plant Mol Biol 45:655-662

Loya Y, Sakai K, Yamazoto K, Nakano Y, Sambali H, Van Woesik R (2001) Coral bleaching: the winners and the losers. Ecol Lett 4:122-131

Malanga G, Puntarulo S (1995) Oxidative stress and antioxidant content in Chlorella vulgaris after exposure to ultraviolet-B radiation. Physiol Plant 94:672-679

Nakamura T, Van Woesik R (2001) Water-flow rates and passive diffusion partially explain differential survival of corals during the 1998 bleaching event. Mar Ecol Prog Ser 212:301-304

Nishiyama $\mathrm{Y}$, Yamamoto $\mathrm{H}$, Allakhverdiev SI, Inaba $\mathrm{M}$, Yokota A, Murata N (2001) Oxidative stress inhibits the repair of photodamage to the photosynthetic machinery. EMBO (Eur Mol Biol Organ) J 20:5587-5594

Niyogi KK (1999) Photoprotection revisited: genetic and molecular approaches. Annu Rev Plant Physiol Plant Mol Biol 50:333-359

Palisano JR, Wayne PL (1972) Acid phosphatase activity and ultrastructure of aged cells of Euglena granulata. J Phycol 8:81-88

Ralph PJ, Gademann R, Larkum AWD (2001) Zooxanthellae expelled from bleached corals at $33^{\circ} \mathrm{C}$ are photosynthetically competent. Mar Ecol Prog Ser 220:163-168

Royall JA, Ischiropoulos H (1993) Evaluation of 2', 7'-dichlorofluorescin and dihydrorhodamine 123 as fluorescent probes for intracellular $\mathrm{H}_{2} \mathrm{O}_{2}$ in cultured endothelial cells. Arch Biochem Biophys 302:348-355

Salih A, Hoegh-Guldberg O, Cox G (1998) Bleaching responses of symbiotic dinoflagellates in corals: the effects

Editorial responsibility: Otto Kinne (Editor),

Oldendorf/Luhe, Germany of light and elevated temperature on their morphology and physiology. In: Greenwood JG, Hall NJ (eds) Proc Australian Coral Reef Soc 75th Anniversary Conf, University of Queensland, Brisbane, p 199-216

Tomas RN, Cox ER (1973) Observations on the symbiosis of Peridinium balticum and its intracellular alga. I. Ultrastructure. J Phycol 9:304-323

Trench RK (1974) Nutritional potentials in Zoanthus sociathus (Coelenterata, Anthozoa). Helgol Wiss Meeresunters 26: $174-216$

Trench RK (1987) Dinoflagellates in non-parasitic symbioses. In: Taylor FJR (ed) The biology of dinoflagellates. Blackwell, Oxford, p 530-570

Vardi A, Berman-Frank I, Rozenberg T, Hadas O, Kaplan A, Levine A (1999) Programmed cell death of the dinoflagellate Peridinium gatunense is mediated by $\mathrm{CO}_{2}$ limitation and oxidative stress. Curr Biol 9:1061-1064

Veldhuis MJW, Kraay GW, Timmermans KR (2001) Cell death in marine phytoplankton: correlation between changes in membrane permeability, photosynthetic activity, pigmentation and growth. Eur J Phycol 36:167-177

Warner ME, Fitt WK, Schmidt GW (1996) The effects of elevated temperature on the photosynthetic efficiency of zooxanthellae in hospite from four different species of reef coral: a novel approach. Plant Cell Environ 19:291-299

Warner ME, Fitt WK, Schmidt GW (1999) Damage to photosystem II in symbiotic dinoflagellates: a determinant of coral bleaching. Proc Natl Acad Sci USA 96:8007-8012

Yentsch CM, Cucci TL, Phinney DA, Selvin R, Glover HE (1985) Adaptation to low photon flux densities in Protogonyaulax tamarensis var. excavata, with reference to chloroplast photomorphogenesis. Mar Biol 89:9-20

Yonge CM, Nicholls AG (1931) Studies on the physiology of corals. IV. The structure, distribution, and physiology of the zooxanthellae. Scientific Report of the Great Barrier Reef Expedition 1928-1929. British Museum (Natural History), London, p 135-176

Zhu H, Bannenberg GL, Moldeus P, Shertzer HG (1994) Oxidation pathways for the intracellular probe $2 ', 7^{\prime}$-dichlorofluorescein. Arch Toxicol 68:582-587

Submitted: September 29, 2003; Accepted: January 20, 2004 Proofs received from author(s): April 26, 2004 